\title{
Signal Transducer and Activator of Transcription 4
}

National Cancer Institute

\section{Source}

National Cancer Institute. Signal Transducer and Activator of Transcription 4. NCI

Thesaurus. Code C28665.

Signal transducer and activator of transcription 4 (748 aa, $\sim 86 \mathrm{kDa}$ ) is encoded by the human ST AT 4 gene. This protein is involved in transcriptional activation and signal transduction. 